\title{
Return rates from intertidal foraging from Blombos Cave to Pinnacle Point: understanding early human economies.
}

Jan C. De Vynck ${ }^{1}$, Robert Anderson ${ }^{2}$, Chloe Atwater ${ }^{3}$, Richard M. Cowling ${ }^{4}$, Erich C. Fisher $^{3}$, Curtis W. Marean ${ }^{3,5}$, Robert S. Walker ${ }^{6}$, Kim Hill $^{3 *}$

1. Centre for Coastal Paleosciences, Nelson Mandela Metropolitan University, PO Box 77000, Port Elizabeth, 6031, South Africa

2. Fisheries Branch, Department of Agriculture, Forestry and Fisheries, Pvt Bag X2,

Roggebaai, South Africa and Department of Biological Sciences and Marine Research Institute, University of Cape Town, South Africa

3. Institute of Human Origins, School of Human Evolution and Social Change, PO Box 872402, Arizona State University, Tempe, AZ 85287-2402, USA

4. Botany Department, Nelson Mandela Metropolitan University, PO Box 77000, Port Elizabeth, 6031, South Africa

5. Centre for Coastal Palaeoscience, Nelson Mandela Metropolitan University, Port

Elizabeth, Eastern Cape 6031, South Africa

6. Department of Anthropology, University of Missouri, Columbia MO, USA

* Corresponding author: Kim Hill, Kim.Hill@asu.edu 


\begin{abstract}
The south coast of South Africa provides the earliest evidence for Middle Stone Age (MSA) coastal resource exploitation by early Homo sapiens. In coastal archaeology worldwide, there has been a debate over the general productivity of intertidal foraging, leading to studies that directly measure productivity in some regions, but there have been no such studies in South Africa. Here we present energetic return rate estimates for intertidal foraging along the southern coast of South Africa from Blombos Cave to Pinnacle Point. Foraging experiments were conducted with Khoi-San descendants of the region, and hourly caloric return rates for experienced foragers were measured on 41 days near low tide and through three seasons over two study years. On-site return rates varied as a function of sex, tidal level, marine habitat type and weather conditions. The overall energetic return rate from the entire sample $\left(1,492 \mathrm{kcal} \mathrm{hr}^{-1}\right)$ equals or exceeds intertidal returns reported from other hunter-gatherer studies, as well as measured return rates for activities as diverse as hunting mammals and plant collecting. Returns are projected to be exceptionally high $\left(\sim 3,400 \mathrm{kcal} \mathrm{hr}^{-1}\right.$ for men, $\sim 1,900 \mathrm{kcal} \mathrm{hr}^{-1}$ for women) under the best combination of conditions. However, because of the monthly tidal cycle, high return foraging is only possible for about 10 days per month and for only 2-3 hours on those days. These experiments suggest that while inter-tidal resources are attractive, women and children could not have subsisted independently, nor met all their protein-lipid needs from marine resources alone, and would have required substantial additional energy and nutrients from plant gathering and/or from males contributing game.
\end{abstract}

Keywords: shellfish, intertidal foraging, South Africa, human evolution 


\section{Introduction}

Hominins have been exploiting intertidal marine resources since the Middle Pleistocene (Colonese et al., 2011), but a coastal adaptation where exploitation is structured around tidal cycles and marine invertebrates constitute a critical portion of the diet appears restricted to Homo sapiens. This coastal adaptation first appears around 110 thousand years ago (ka) at a series of sites in South Africa (Marean, 2011, 2014). The south coast of South Africa has the oldest and best evidence for intensive use of coastal resources by early Homo sapiens, including various Middle Stone Age (MSA) sites such as Pinnacle Point 13B (Jerardino and Marean, 2010), Blombos Cave (Henshilwood et al., 2001; Langejans et al., 2012), and Klasies River Mouth (Voigt, 1973; Thackeray, 1988). In Later Stone Age (LSA) sites dating to the Holocene, the increased intensity of intertidal foraging in the region is signalled by very large shell middens, taxa-specific foraging, taxonomic evidence for foraging very deep in the intertidal zone (Marean et al., 2014), and reductions in mollusk size (Klein and Steele, 2013).

Various researchers have proposed that intensive coastal resource use may have been a significant factor in the evolution of cognition (Broadhurst et al., 2002), development of social complexity (e.g., Whitaker and Byrd, 2014), the maintenance of population refugia through unfavorable periods (Marean, 2011, 2014), and the dispersal of humans around the world (e.g., Fa, 2008; Codding et al., 2014). Importantly, early evidence of human "behavioral modernity" in southern Africa seems to roughly correspond to the period when intertidal resources become increasingly visible in the archaeological record (Marean, 2014). The productivity of rich coastal resources supplemented with diverse geophyte plants have been hypothesized to be resistant to the 
impacts of glacial cooling, thus rendering the Cape Floristic Region (CFR) as a population refuge during glacial cycles (Marean, 2010, 2011). Linguistic and genetic data corroborate the hypothesis that the CFR constituted a Pleistocene hominin refuge (e.g., Tishkoff et al., 2009; Henn et al., 2011; Kim et al., 2014). However, to date there has been little empirical evidence on the potential foraging returns from intertidal resources in the CFR coastal environment, despite excellent marine foraging studies in other areas of the world.

Coastal intertidal resources have often been regarded as a low income fallback, or low-risk option for hunter-gatherers, with hunting, fishing, and plant gathering as more energetically efficient foraging activities. Because active adults in foraging societies generally provision a number of dependent juveniles, pregnant and lactating females, and elderly band members (Hill and Hurtado, 2009), low-return foraging options could not be the primary focus for daily subsistence by provisioners in a cooperative breeding social system. But Meehan's (1982) seminal study on Anbarra coastal foragers led many anthropologists to question the view that shellfish were only a fallback resource. Subsequently, others also challenged the notion that shellfish gathering is inherently a low-return activity, emphasizing the importance of protein that marine foraging provides in carbohydrate rich plant based diets (e.g., Erlandson, 1988, 2001).

If intertidal foraging is highly productive relative to other subsistence options, the presence of dense, predictable and defensible resources in a coastal region might imply the origins of other behavioral adaptations such as territorial defense, emergent hierarchical social structure and intense intergroup competition that could drive important changes in human cooperation and social structure (Dyson-Hudson and Smith, 1978; 
Marean, 2014). Importantly, intertidal foraging might provide a stable and relatively low depletion resource base for human foragers. The strong seasonal fluctuations that characterize terrestrial foraging might be absent in marine foraging economies, providing a more reliable year-round resource base. Likewise, whereas terrestrial prey generally cannot be harvested at greater than $5-50 \%$ of the standing biomass annually (Robinson, 2000), and immobile marine species are sensitive to intensive harvesting (Lambert and Steinke, 1986; Dye, 1992; Lasiak and Field, 1995), it appears that mobile invertebrates can be harvested at rates of more than $100 \%$ of the standing biomass per year, due to rapid migration from inaccessible infratidal zones and potentially explosive reproductive potential (e.g., Siegfried et al., 1985). The dichotomy between sessile and mobile intertidal resources is critical, and ignoring this distinction has sometimes led to contradictory conclusions about the sustainability of marine foraging (Hockey and Bosman, 1986; Lasiak and Field, 1995; Lasiak, 1999).

The prevalence of shell middens throughout prehistory and the debate about the impact of marine foraging on human evolution has sparked multidisciplinary research to investigate marine foraging, primarily through archaeological, ethnographic, and experimental return rate studies. While archaeological examples provide insight on prehistoric economies, middle-range ethnographic and experimental studies have been critical in helping interpret the behaviors that created archaeological shell middens (Meehan, 1982, 1983; Bird, 1997; Bird and Bliege Bird, 1997; Bird et al., 2002; Thomas, 2002, 2007; Thomas, 2008). Some archaeological studies of shellfish midden patterns analyzed from a behavioral ecology perspective are available, (for illustrative examples, see Steele and Klein, 2008; Langejans et al., 2012; Klein and Steele, 2013), however, our 
goal in this paper is to determine experimentally what the marine intertidal foraging economy might look like under present coastal conditions, not to model transport and archaeological assemblage patterns. Nevertheless, data we present here are obviously relevant to such questions.

Ethnographic studies of marine foraging and shell midden formation have emphasized the role of prey selection and field processing of shellfish (Meehan, 1982, 1983; Bird, 1997; Bird and Bliege Bird, 1997, 2000; Bird et al., 2002; Thomas, 2002, 2007; De Boer et al., 2002). While the goal of midden research is often to reconstruct unobserved economies, field processing of many species reduces overall transport time required to provision consumers at a home base (Metcalfe and Barlow, 1992) hence, beyond a threshold transport distance, middens will not accurately reflect harvest patterns (Meehan, 1982; Bird, 1997; Bird and Bliege Bird, 1997; Bird et al., 2002; Thomas, 2002, 2007). This means that experimental foraging will often be required in order to determine optimal sets of prey, overall harvest return rates, and the likely contribution of different species to the foraging diet in a particular region or habitat. Likewise, when children exploit easy to encounter prey we may observe an overrepresentation of low-ranked prey in shell middens (Bird and Bliege Bird, 2000), but direct observation of foraging will provide a clear indication of which species are likely to have been economically important to adult foragers and why.

Finally, prior experimental studies have been conducted to estimate the patterns of shellfish foraging depletion rates, especially focusing on California (Jones and Richman, 1995; Kennedy, 2004; Whitaker, 2008), but also covering southern Africa, though not the Cape Floral region (Hockey et al., 1988; Branch, 1992; Kyle et al., 1997 a,b; Tomalin 
and Kyle, 1998; De Boer et al., 2002). Predicting longitudinal changes in prey

availability due to exploitation will be critical for projecting experimental patterns into the past. Because of this, our research team has been collecting long term data on harvest based depletion in designated coastal plots, and will present these results in a subsequent publication.

The research described here builds upon prior knowledge by measuring and reporting caloric return rates of marine foraging in a previously unstudied region where some of the earliest evidence of shellfish exploitation has been uncovered (Marean, 2014). In addition, we use multivariate statistics to investigate the effect of tidal level, habitat type and weather patterns, as well as age and sex of the forager on measured shellfish return rates. The importance of these factors have been acknowledged but not been estimated with appropriate statistical controls (Bird, 1997; Bird and Bliege Bird, 1997; De Boer et al., 2002; Thomas, 2002; Fa, 2008). We hope to apply this information to the archaeological record in South Africa in order to understand better the potential role of shellfish in the development of cognitive capacities required to predict tidal cycles and the possible emergence of social systems with inheritance rules and territoriality-based cooperative in-group behavior.

\section{Material and methods}

Study Site

Ethical permissions for this study were granted by Arizona State University IRB Protocol 1301008742. The sample area consisted of the coastline of South Africa's

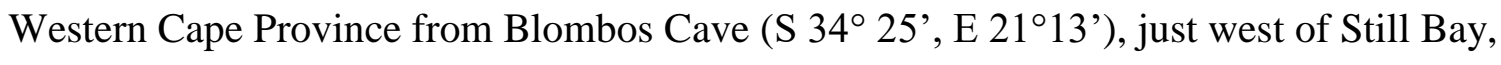
to Pinnacle Point (S 3412’, E $22^{\circ} 5^{\prime}$ '), just west of Mossel Bay. This stretch reaches to 
two important archaeological sites, and samples a significant portion and representative array of south coast habitats. The local coastline has a physiography dominated by a logspiral structure where rocky headlands of resistant geology, normally quartzitic sandstone of the Table Mountain Group (TMS), are separated by half-moon bays eroded into less resistant rocks, normally shales. The former are typified by rocky inter-tidal zones, while the latter normally have sand beaches and sometimes reefs of lithified and horizontallyplaned sands (aeonialite). The vegetation of the immediate hinterland is strandveld, a dense thicket of evergreen shrubs. Despite high bluffs in some places, and the dense vegetation, the entire coast could be traditionally accessed by descending one of numerous trails and then walking along the exposed shoreline. The intertidal zone is mainly composed of quartzitic sandstone outcrops, sand beaches, aeolianite, and the estuaries of the Gouritz and Goukou Rivers. A team of marine scientists under the direction of one of us (RA) walked the entire coastline at low tide in $2013-2014$. The low tide coastline segments thus evaluated add up to 100.3 linear km from Blombos to Pinnacle Point. The mapping team coded each 100 meter segment of coastline into one of six intertidal habitat types relevant to human foraging: 1) estuary; 2) sand beach; 3) aeolianite reef; 4) TMS boulders; 5) TMS rocky headlands; and 6) TMS wave-cut platforms (Figure 1). Estuaries comprised only about 300 meters of this coastal strip and were not sampled for foraging returns because our participants did not identify any profitable resources that can be exploited with traditional technology in this habitat type. Sand beach made up about a fourth of the coastal sample but was notably unproductive and avoided by our foraging subjects except on two experimental days when we requested them to forage there (reported below). The remainder of the coast is composed 
of four highly productive habitats for marine-intertidal foraging (17.6\% aeolianite reef, 35.2\% TMS rocky headlands, 14\% TMS wave-cut platforms, and 6.1\% TMS boulders), that make up most of the coast from Blombos to Pinnacle Point.

\section{[FIGURE 1 HERE]}

Daily fluctuation in sea level along the South African coast is determined primarily by lunar phases with most extreme tidal height fluctuation occurring during the spring phase that peaks at the new moon and full moon of each lunar month. Neap and interim tides show considerably less tidal height fluctuation. Tidal charts predict hourly sea level in meters above reference lowest water level corresponding to the Chart Datum or Lowest Astronomical Tide (LAT). During our study periods the mean low water level of spring tides was +0.28 meters, and the mean low water level of neap tides was +0.52 meters. Average high tide for our sample days was +2.04 meters; thus, enthusiastic foraging took place on days when sea levels had generally dropped about 1.7 meters from that day's high tide. Sea level in the study area also varies in relation to wind and barometric pressure (Mather et al., 2009; Chandler and Merry, 2010). These variations can cause sea level changes of about $1 \mathrm{~cm}$ per millibar. This implies that a strong high pressure system can lower sea level by up to $20 \mathrm{~cm}$ or more irrespective of tidal levels. The absolute maximum difference between highs of $1040 \mathrm{mb}$ and $990 \mathrm{mb}$, as quoted in the SA Navy tide tables, would correspond to a sea level change of around $50 \mathrm{~cm}$ (S.A. Navy, 2015), significantly augmenting the effect of lunar tides. In addition to tides and atmospheric pressure, strength of swells is an important determinant of prey accessibility, since strong swells can erase access afforded by low tidal levels. Swell strength is a function of open ocean wind and storm strength and direction of prevailing winds. Wind 
shifts seasonally, coming mainly from the WSW in the winter and the E in summer. Hard winds (Beaufort rating 6+, swells $2.5 \mathrm{~m}-6+\mathrm{m}$ ) blow about eight days per month from June through September, but only about five days per month the rest of the year. On such days foraging is avoided due to the violent seas and dangerous conditions, regardless of tide. Calm or gentle breezes blow on 5-12 days per month (Beaufort rating $0-3$, swells $0-1 \mathrm{~m}$ ), whereas moderately stiff breezes (Beaufort rating $4-5$, swells $1-$ $2.4 \mathrm{~m}$ ) are typical of about half the days of each month (wind data from Wisuki, 2015). Wave patterns generally follow wind conditions, with large breakers $(3+\mathrm{m})$ typical on about half the days of the month from June through September. Breakers can be quite dangerous to foragers, and in one case a man participating in our study was washed into the sea and thoroughly thrashed against the rocks before barely escaping with his life. Small waves $(<2 \mathrm{~m})$ characterize about seven days per month in the remainder of the year and make for most attractive foraging conditions. Waves almost always come from the SW and hence SE facing shorelines are protected from difficult weather conditions, and are preferred when available. In sum, wave and wind conditions are generally worse in the cold winter months, and calm days are more likely in the summer.

Weather patterns in the study region are generally mild and hospitable for humans, but can be challenging at times. Seasonality in rainfall is almost non-existent with precipitation on $7-9$ days per month and monthly totals between $20-40 \mathrm{~mm}$. Heavy rain that precludes foraging falls about two days per month on average, whereas other days, even with light rain, are considered suitable for foraging. Maximum summer temperatures average about $27^{\circ} \mathrm{C}$ in January and February, with minimum winter temperatures averaging only $5^{\circ} \mathrm{C}$ in July (World Weather Online, 2015). Because spring 
low tides often occur near dawn and foraging requires wading in knee- to waist-deep water, foraging in mid-winter can be a very chilly experience. On warmer foraging days however, our subjects (men in particular) sometimes submerged themselves completely in attempts to dislodge favored prey.

Foraging observations

Marine intertidal return rates were measured by observation of partially supervised food collection with experimental subjects from local populations. During foraging bouts we transported foragers to preselected locations, and we chose the approximate starting time of each foraging day. Habitats were selected based on coastline mapping to ensure good representation of the four important rocky habitat types, and the sample was constrained to areas where we could obtain permission to cross private land for coastal access. All experimental sites were protected by strict harvest laws and we observed other collectors at our chosen site on only one time during the entire sample period. Harvest sites did not contain invasive species and were not subject to legal human exploitation in the past 20 years or so (shellfish beds were at or near carrying capacity, the size of Turbo sarmaticus shells was as large as in the most highly protected areas of the south coast). These coastal habitats are the closest modern analogy to the early Holocene and Pleistocene paleoenvironment during periods when the sea level was near its present state. Geology of the area implies that habitat structure would be very similar if sea levels were approximately the same in the past. Vastly lower sea levels, typical of interglacial periods, would have exposed a very different shoreline but perhaps with the same set of coastal rocky habitats. Since our ultimate goal is to project 
foraging patterns to earlier time periods, measuring the return rates and prey composition in each habitat type was a high priority for the study.

After arrival at a selected foraging location well before low tide, subjects were free to commence harvesting however and wherever they chose, and for as long as they wished. Foragers were not subject to size or species harvest restrictions but were told that they would be allowed to process, cook, and consume some of each harvest with their families in order to obtain data on edible portion and processing times. We observed and timed foraging activities, recorded habitat and weather data, and weighed all collected resources approximately once in each 20 to 60 minute interval (termed a foraging "bout"). These methods allowed us to statistically model foraging return rates as a function of immediate local conditions (wind, tidal level, habitats). Tidal levels were calculated by interpolating between published high and low tide levels from a local tide gauge (Mossel Bay tide gauge station) at known times, and corresponding to the midpoint time of the observed bout.

Because one of us (JDV) has resided in the study region for the past 19 years, experimental subjects were recruited informally by acquaintance and word of mouth from the communities of Melkoutfontein, Gouritz River Mouth, and Arniston in the region near Still Bay, Western Cape Province. Subjects reported themselves to be descendants of the ancestral coastal Khoi-San population of the region, and live in small communities within a few kilometers of the coast. All subjects had considerable prior experience collecting marine intertidal foods for personal consumption. The pool of subjects included 34 men, aged 12 to 63, and 13 women, aged 9 to 54. They contributed 293 hours of observed foraging during 41 diurnal low tides (no night foraging was observed) 
that took place in the months of March, April, June, July, September, October, November, and December. Tidal levels during sample bouts ranged from $0.15 \mathrm{~m}$ to $0.94 \mathrm{~m}$. Each day of the sample was assigned a composite score for "weather conditions" based on wind speed, wave height, and shore aspect (whether the shore directly faced into the oncoming swell). These composite scores were then assigned arbitrary ranks from 1 (Beaufort wind rating $0-2$ : best conditions, no wind, small waves, protected shoreline) to 5 (Beaufort wind rating 6+: worst conditions - impossible to forage). Table 1 shows the sample composition of all bouts observed on rocky coastline substrate (sand beach foraging is described separately below).

Foraging days generally began about $1-2$ hours before low tide and continued for about $1-2$ hours after low tide. During the study we conducted foraging bouts from 6 days before to 6 days after peak spring tide, but the vast majority of days sampled were in the range from \pm 2 days around peak spring tide (full moon and new moon). Research subjects showed little interest in foraging outside this time window, and the relationship between foraging return rates and tidal level (see below) clearly illustrates why. The mean foraging time from start to finish for individuals in our sample was 127.3 minutes per forager per day.

\section{[TABLE 1 HERE]}

\section{Food value}

The foraging harvest was composed of 22 edible invertebrate species (Table 2). Each species collected during a foraging bout was separated and weighed in a light plastic bag using digital hanging weigh scales. Multiple items of the same species (e.g., 57 individuals of $T$. sarmaticus) were generally weighed together to the nearest 10 grams, 
whereas single items (e.g., one limpet) were weighed to the nearest gram. The edible portion of each species was calculated by weighing field collected items, then allowing the study subjects to cook and extract the edible flesh weighed again, or by weighing the refuse after consumption. The edible portion of each species was then converted into a caloric value using published nutrient content of a similar marine invertebrate species (Suuplementary Online Material (SOM)). Because all resources were consumed cooked, we estimated cooked edible portion and used nutrient values of cooked portions when possible. The mean energetic density of resources harvested was $843 \mathrm{Kcal} / \mathrm{kg}$ raw edible portion, and $1115 \mathrm{Kcal} / \mathrm{kg}$ cooked edible portion (Table 2). The mean overall energetic densities are comparable to those reported by Bird (1997) with $724 \mathrm{Kcal} / \mathrm{kg}$ raw edible for bivalves and $997 \mathrm{Kcal} / \mathrm{kg}$ raw edible for gastropods based on nutrient analyses of eight species.

\section{[TABLE 2 HERE]}

\section{Statistical analyses}

The field observations were coded into a database in which each time period between weighing constituted one "bout", and each resource collected during a bout composed a single row entry. The database contained 531 foraging bouts ranging from eight minutes to 125 minutes duration, (mostly between 20 and 60 minutes). While we tried to weigh all collected items about once each half hour, sometimes subjects became spread very far apart and we were unable to find all of them, which led to a few very long bouts. A few short bouts took place after weighing when subjects began to forage again for a few minutes and then decided that tidal conditions were unfavorable and they wished to terminate the foraging day. 
For each bout, we recorded forager ID, age and sex, habitat type, weather condition, and tidal level as predicted by local tide charts. These comprised the set of independent variables entered simultaneously into a statistical model designed to estimate their respective independent effects on the dependent variable, caloric return rate of the bout $\left(\mathrm{kcal} \mathrm{hr}^{-1}\right)$. The distribution of return rates for the 531 bouts is strongly right skewed (Figure 2), suggesting that a multiplicative set of interacting causes determines bout return rate (the natural log of all bout return rates is normally distributed). Because longer bouts constitute better measures of overall return rate, our regression model weighted observations by foraging bout time. Likewise, because individuals were resampled over multiple bouts, a general linear mixed models (GLMM) including random effects for each individual was employed. The GLM model assumes that individual differences in foraging ability are normally distributed, and controls for those differences while examining the linear relationship between other variables and the dependent variable of interest, using maximum likelihood procedures. Fixed effects in our regressions included categorical variables for sex, weather conditions, and habitat type, and the continuous variables age and tidal level. In order to fulfill the assumption of normal distribution of errors, three different models were examined that treat right skew in the data differently: a GLM model using the natural log transformed dependent variable (multiplicative geometric mean model); a GLM model with gamma probability distribution and a log link (multiplicative arithmetic mean model); and a GLM model with gamma probability distribution and the identity link (additive arithmetic mean model). The second of these models was chosen for presentation here because it resulted in the lowest Akaike information criterion (AIC) values. All three models found significant effects of the 
random variable (ID) and all fixed variables except age (ie. sex, habitat, weather, tidal level).

\section{[FIGURE 2 HERE]}

We used the gamma distribution log-linked GLMM to calculate marginal means under specified conditions. This procedure employs the regression coefficients to predict return rates for different independent variable values with all other variables controlled at their sample mean values. Error bars for the marginal means represent $95 \%$ confidence intervals. Average foraging return rates for males and females were calculated from the gamma log-link mixed model with age set to 30 years, tidal level set at the mean of $0.5 \mathrm{~m}$, weather effects calculated from the observed frequencies in the sample, and habitat types set to their observed frequencies in the sample. Estimated return rates for the best and worst set of conditions were also calculated using the coefficients from the same GLMM. Best conditions were defined tidal level $0.15 \mathrm{~m}$ (the sample minimum), most favorable weather conditions, and the highest return habitat (aeolianite). Predicted return rate under worst conditions was estimated for tidal level $0.94 \mathrm{~m}$ (the sample maximum), and the worst weather conditions and worst habitat type (TMS boulders).

\section{Results and preliminary discussion}

The total energetic harvest was estimated at just under 440,000 Kcal (Table 2) from 138 person days (35 woman days, 103 man days) of foraging on rocky coast, and six man days of foraging on sand beach for Donax serra (locally called sand mussel, or clam). The harvest data suggest that only a few classes of invertebrates would dominate the contribution to a potential foraging diet in the region (Figure 3); T. samarticus (alikreukel, or turban snail) two types of abalone (Haliotis spp.), and brown mussel 
(Perna perna) together comprised $89 \%$ of all energy harvested. The six person days foraging on sand beach yielded only 1,755 total Kcal of D. serra for an on-site collecting return rate of only $87 \mathrm{kcal} \mathrm{hr}^{-1}$. Subjects foraged on sand beach for the bivalve mollusk $D$. serra, only because we requested them to do so; they would not have ever chosen this habitat if not for our experimental request. The low return rates clearly explain why, however we are still unsure why D. serra shells are found in several shell middens in the region at substantial densities. Because of the low forager interest and low productivity, sand beach experimental data were eliminated from all subsequent analyses in this paper.

As a crude return rate for the recorded foraging sample, we can calculate daily mean harvest of 3,165 Kcal/forager day, and an overall sample return rate of 1,492 Kcal per forager hour collecting on site (not including processing time). These are calculated by dividing the total $436,816 \mathrm{Kcal}$ collected by the observed 138 person days and 17,572 minutes collecting time, respectively.

\section{[FIGURE 3 HERE]}

The gamma GLM regression model of bout return rate with five independent variables and a random effect controlling for repeated observations of individuals, shows that sex of forager, habitat type, weather conditions and tidal height are all associated with significant differences in return rates (Table 3). The effect of age is insignificant. The regression coefficients from the GLM model can be used to calculate predicted marginal mean return rates associated with different conditions and other variables controlled at sample mean values and set to the return rate of the average forager in the sample. The predicted marginal mean return rates are generally lower than the long-term crude sample mean (the predicted marginal mean from the overall model is $863 \mathrm{kcal} \mathrm{hr}^{-1}$ ), 
because the random effects model adjusts the predicted values to that of an average forager whereas our raw field sample included several high return foragers that also contributed a higher proportion of all foraging bouts (see below). The GLMM regression predicts that a 30 year old average male forager should obtain a mean of $1,236 \mathrm{kcal} \mathrm{hr}^{-1}$ under average weather, habitat and tidal conditions and that an average 30 year old female should obtain about $685 \mathrm{kcal} \mathrm{hr}^{-1}$ under the same conditions (Figure 4a). Habitat differences in return rates range about three-fold, with aeolianite being most productive and TMS boulders least productive (Figure $4 \mathrm{~b}$ ). Weather patterns produce almost a fourfold difference in return rates with all other variables controlled (Figure 4c).

\section{[TABLE 3 HERE]}

\section{[FIGURES 4a-c HERE]}

There is no reason to expect the return rates as a function of continuous variables such as age or tidal level to be linear, so we examined the shape of these relationships by applying a LOWESS smooth to the residual values from regressions that controlled for all other effects (Figures 5a, b). Visual inspection shows that the relationship between age and foraging returns (Figure 5a) is trivial in our sample (the slope was slightly negative but not significant). Idiosyncratic differences based on foraging experience, skill and strength cause small increases or decreases and appear to overwhelm any underlying age pattern that might exist. Tidal level (Fig 5b), on the other hand, is clearly associated with a large effect. The shape of this relationship can be visualized by plotting the difference between observed bout return rates and the predicted return rates given the effects of all other variables in a GLM model (i.e., residuals of the GLMM without "tide level" as a variable). The bouts with the lowest $10 \%$ of the tidal levels show a mean of residuals of 
more than $500 \mathrm{kcal} \mathrm{hr}^{-1}$ above the predicted for those days (given other variable effects), and the highest $10 \%$ of tidal levels show a mean of residuals of nearly $700 \mathrm{kcal} \mathrm{hr}^{-1}$ lower than predicted based on the effect of other variables. This trend is confirmed by the complete GLM model (Table 3), in which "tide level" has a coefficient that implies that foraging returns vary two-and a half-fold from lowest to highest tidal levels when all other variables are controlled.

[FIGURES 5a-b HERE]

\section{[FIGURE 6 HERE]}

Inspection of the raw data also allows us to examine individual variability in returns. Figure 6 shows the return rates for 11 individuals who were monitored for at least eight hours of foraging on at least four different days. Overall return rates (total Kcal obtained/total time foraging) for different individuals varied by more than ten-fold in our sample. Some of this variation may be related to specific individuals being sampled on exceptionally good or poor days, but the statistical significance of the random variable in our GLM models implies that even with all other variables controlled, some foragers obtain significantly higher return rates than others. The best two foragers, for whom we have a combined total of 49.4 hours of observation, obtained overall return rates of 2,862 and 2,217 Kcal hr${ }^{-1}$ despite foraging in all habitats and all weather conditions.

Finally, we can use the GLMM regression equation to predict return rates for a typical man or woman under the best and worst set of conditions. When the tide is at its lowest level in our sample, the weather conditions are best, and people forage on aeolianite reefs, young men and women are predicted to obtain means of 3,371 Kcal hr-1, 
and 1,869 $\mathrm{Kcal} \mathrm{hr}^{-1}$ respectively. When the tide is at its highest level in our sample, weather conditions are the worst, and people forage on TMS boulders, older men and women are predicted to obtain means of $325 \mathrm{Kcal} \mathrm{hr}^{-1}$ and $180 \mathrm{Kcal} \mathrm{hr}^{-1}$ respectively. Clearly, choosing the right habitat and right conditions is critical for obtaining return rates high enough to support a family.

\section{Processing times}

Foragers often cooked and ate most of their harvest at the foraging site, but also carried bags of raw or cooked food back to family members remaining at the village settlement. When transport was a goal, all univalves were shelled (using a small knife or screwdriver), but bivalves and other foods were carried home whole. Oysters were never transported, but always eaten raw at the foraging site. Because processing and cooking was often carried out at home by non-foragers, and outside regular foraging hours, processing time was not mutually exclusive with foraging and should not be theoretically relevant to prey, patch, and habitat choice decisions often modeled using optimal foraging theory (OFT; Hill et al., 1987). Nevertheless, we report processing times here in order to provide full information about the costs of dietary reliance on these resources.

T. sarmaticus were usually cooked in batches of 15 to 20 shells placed directly on the coals. Cooked as batches this way, the mean required cooking time was only 27 seconds per item. Extracting the meat from the shell and removing the guts prior to consumption took 18 seconds on average (no variance was measured because numbers are calculated from a single large batch). Haliotis spp. required 20 seconds on average to extract from their shell and remove guts, and one minute to cook per item when cooked in batches of 10 items. Small periwinkles (Oxystelle spp.) required 28 seconds per item 
to cook in large batches, and another six seconds per item to extract the edible portion. Limpets required an average of 36 seconds per item to cook in batches and were extracted in a few seconds prior to consumption. Cooking did not require constant attention in any case, but instead took place while foragers were conversing, socializing, repairing tools, packing up other items, and so on. Firewood collection usually required $10-20$ minutes in order to cook up an entire day's harvest. For a quick subsample of one daily harvest we measured that $77.1 \mathrm{~kg}$ live weight of mixed shellfish required $22.3 \mathrm{~kg}$ firewood that was collected in 45 person minutes. This would mean that it takes about 20 minutes for three people to collect the firewood necessary to cook $100 \mathrm{~kg}$ of shellfish at the foraging site.

Putting together the above information and the values from Table 2, we can estimate that if the mean overall return rate of $\sim 1400 \mathrm{kcal} \mathrm{hr}^{-1}$ were composed entirely of T. sarmaticus, about 8 minutes would be required to collect the firewood needed, and another 45 minutes to cook that amount of $T$. sarmaticus. Cooking, however, generally takes place while engaging in other activities, and extraction of the meat from the shell is usually part of consumption (not normally considered processing time in OFT models). The subsequent mean return rates counting costs of collecting firewood and cooking, if the main harvest species was $T$. sarmaticus, would then drop from about 1,400 $\mathrm{kcal} \mathrm{hr}^{-1}$ to about $740 \mathrm{kcal} \mathrm{hr}^{-1}$.

On quite a few occasions, large batches of shellfish were field processed before transport home. Table 4 shows some measured processing times per kilogram live weight to extract the edible portion of T. sarmaticus, Haliotis spp., Cymbula spp., and Scutellastra spp., before transporting them home to cook. Foragers required, on average, 
about 9.3 minutes to collect a kilogram of shellfish at low tide, and about 2.4 minutes per kilogram, on average, to extract the edible portion of those shellfish to transport home. In sum, extraction-from-shell processing times appear to require about $20 \%$ of all time required to obtain and prepare major marine resources for transport $(P$. perna were never field processed). This implies that on-site return rates, including processing for field transported species, are about $80 \%$ of the on-site harvest return rates reported in this study. But when families camp on the coast while collecting, most processing can be done by non-foragers, or during times when foraging is not possible, and extraction of the edible portion after cooking is part of consumption not forager handling time. Hence the measured collection rates excluding processing that we report throughout most of this paper are appropriate for modeling decisions about whether rate maximizing foragers should exploit shellfish or favor other economic alternatives such as plant gathering or hunting.

\section{[TABLE 4 HERE]}

\section{Discussion}

Observations on intertidal foraging along the southern Cape coast of South Africa suggest that men and women with simple tools could extract energy and protein along large stretches of the coast at rates that compare favorably with the returns from terrestrial hunting and gathering in observed modern hunter-gatherer societies (see Table 5). Although methodologies differ somewhat, these measured return rates reveal the comparative efficiency of coastal adaptation on the southern Cape. The current intertidal coastline between Blombos Cave and Pinnacle Point consists of $72 \%$ rocky substratum (TMS and aeolianite) that is highly favorable for marine foraging. This is probably due 
to a combination of high marine productivity stimulated by the meeting of cold and warm currents (Bustamante et al., 1995; Branch and Menge, 2001), and the abundance of species that are edible and vulnerable to human predators (i.e., large sessile mollusks). Our sample of rocky shoreline foraging is large enough (47 male and female foragers from age nine to 63 , observed for 17,572 foraging minutes during 41 tidal cycles over eight months of the year), that generalizations are warranted.

\section{Coastal foraging on the South African coast}

First, almost $90 \%$ of the harvest consists of three species of marine mollusks ( $T$. sarmiticus, $P$. perna, and Haliotis spadicea). This is due partially to selectivity (small species were ignored), partially to abundance (T. sarmaticus is particularly abundant in this region), and partially due to the size of the edible portion of each item collected ( $T$. sarmaticus and $H$. spadicea are some of the largest resources harvested).

Second, the overall return rate of harvest for all men and women in all locations and time periods of our sample was $1,492 \mathrm{Kcal} \mathrm{hr}^{-1}$ after arriving at the coast. We can compare this to a sample of other marine intertidal return rates previously published (highlighted in gray in Table 5) and some of the hunting and gathering return rates that have been measured and widely discussed with respect to forager economies and decisions about patch and habitat exploitation. The return rate that we observed in our experimental sample is higher than the vast majority of measured return rates for on-site ("in-patch") economic activities, or marine foraging returns, even including vertebrate hunting by men in some places (Table 5). Human foragers in this region would probably not have to expand their diet to include marine resources (cf. Compton, 2011). Instead, the marine intertidal foraging habitat would often provide higher energetic returns than 
alternative foraging activities. Additionally, South African marine invertebrates yield protein content which is comparable (in weight ratio) to protein from terrestrial fauna (Kyriacou et al., 2014). This means that while meeting energetic needs marine intertidal foragers could also easily provide sufficient protein in the diet for good health, and might, in fact, need to complement the lean protein shellfish diet with carbohydrate or lipid rich resources to avoid negative consequences of a high protein diet (Speth and Spielmann, 1983).

[TABLE 5 HERE]

Additional resources encountered but not considered in this analysis might raise our estimated mean coastal foraging harvest rate even more. Over the sample period, two Cape fur seals (Arctocephalus pusillis) were encountered by foragers. They would have represented easy and lucrative prey $(80-100 \mathrm{~kg}$ each) to human foragers, as they were resting high above the water level and traversing the rocks to reach the safety of the ocean would have been cumbersome and slow. Also, we observed that the reproductive organs of $T$. sarmaticus were consumed on occasion but we were not able to determine under what conditions they are edible (we treated this as inedible refuse in our experiments). During the month of March, when we saw people eat $T$. sarmaticus gonads, we sampled 117 items and discovered that the edible reproductive organs would have added $1.4 \%$ to the total edible portion.

Third, a variety of factors significantly affect on-site return rates. The predicted return rate, with other variables controlled, at the lowest observed low tidal levels were roughly 2.5 times higher than the expected return rates at the highest low tide levels at which experimental subjects were willing to forage (they were unwilling to forage at all 
during neap tides and high tide levels). Weather conditions were associated with threefold differences in return rates, men obtained about twice as many calories per hour as women, and the best habitat type provided about a 30\% higher return rate than the worst habitat (ignoring sand beaches). The multivariate regression model allows us to predict the expected foraging return rate under the best set of conditions (young, male, lowest tide level, good weather, on aeolianite reefs) compared to the worst combination of conditions (old, female, higher tide level, in poor weather, on boulders). The difference is striking, with the expected returns for men under optimal conditions about 3,400 $\mathrm{kcal} \mathrm{hr}^{-1}$, and for women under the worst conditions less than $200 \mathrm{kcal} \mathrm{hr}^{-1}$. South African intertidal foraging can either be very attractive or unattractive depending on circumstances.

\section{Implications for foraging and social behavior}

Several important implications of these results are evident. First, foragers in current coastline conditions can feed their families very well by exploiting intertidal resources, but only on about $1 / 3$ of the days of the month ( 5 days in each biweekly tidal cycle). On those days, foraging on the coast for $2-3$ hours per day maximum, an average woman might collect some 2,000 Kcal of high protein food. This represents the complete daily nutrient requirement for a woman and part of a juvenile dependent. Older juveniles could acquire this amount as well. If younger juveniles could also help forage for intertidal resources and/or women could spend a couple of hours collecting plants, it is quite feasible that a typical maternal family (one woman and two juvenile children) could survive without requiring allomaternal food subsidies on these days. This would include both the energy and the protein required for adequate growth and development. However, during the remaining two-thirds of the month, intertidal foraging, as we 
observed it, would not be sufficiently productive to meet food needs, and some other high-return source of energy and protein would be required to support dependent offspring. This conclusion might need to be modified, however, if earlier foragers used different technologies, foraged for long hours during low return time periods, or practiced riskier foraging in deeper intertidal zones than we observed. Alternatively, if energy needs could be met by plant foraging, one strategy to obtain optimal protein intake might be to collect surplus mollusks and dry them for later use, since drying mussels has been shown to be feasible in this environment (Henshilwood et al., 1994). We believe these conclusions about marine foraging on the south coast are robust well into the past. Ongoing data collection suggests that foraging with wood or bone tools does not change these measured return rates substantially. We measured crude return rates of 1,589 and $1,672 \mathrm{kcal} \mathrm{hr}^{-1}$ respectively from a small sample of days ( $n=4$ days, $20.65 \mathrm{hrs}$ ) foraging with only wood or bone tools. Additionally, juveniles (ages 9-15) are quite efficient marine intertidal foragers in this area, with an observed crude foraging rate of $1,740 \mathrm{kcal}$ $\mathrm{hr}^{-1}$ ( $n=22.1$ hours). Finally, depletion experiments now being analyzed will allow us to determine whether the levels of harvest that we observed might be sustainable over longer periods of time.

The second implication of our analysis is that tidal level and weather conditions are critical for obtaining high return rates in this region. Weather patterns are not easily predictable days in advance, but tidal levels are. Human foragers that ventured inland in search of other resources would have required the ability to keep track of tidal cycles in order for marine intertidal resources to have been economically important. Alternatively foragers could have stayed on the coast all year, but this would have conflicted with 
exploiting other good plant and animal habitats that are located inland. Recognizing that tidal cycles are associated with observable lunar cycles, and using such cues to begin moving towards the coast days in advance could have been a critical and cognitively demanding step required for human dependence on intertidal resources (Marean, 2010, 2011). This requires knowing that the shape of the moon in the sky on a given night predicts its sequence of shapes on subsequent nights (first growing, then shrinking) and also that full moon and no moon nights correspond to lowest tides on subsequent foraging days. It is unclear whether early hominins attained this level of ability of causal inference, as other apes may not have this ability (Penn and Povinelli, 2007; Penn et al., 2008).

A third implication of our study comes from our finding that aeolianite reefs are more productive than other habitats. Although these formations make up only $15 \%$ of the current coastline, submarine geological studies suggest that this formation is much more common on the submerged Agulhas Plain that would have been exposed through much of the Pleistocene (Fisher et al., 2010; Cawthra, 2014). If so, intertidal foraging might have been even more productive during periods of low sea level in the past.

Finally, when considering economic productivity in the region we note that southern coastal South Africa varies from the west and east coasts in ocean conditions and intertidal community structure and biomass. Each of the adjacent regions has shared, but distinct, intertidal characteristics, with species diversity increasing to the east while biomass decreases (Branch and Branch, 1992; Branch and Menge, 2001). Studies of human foraging on the east coast, while not measuring return rate explicitly, suggest high returns and a similar strong preference for low spring tide collection (Lasiak and Dye, 
1989; Lasiak, 1992; Kyle et al., 1997 a,b; Tomalin and Kyle, 1998). The west coast is still unstudied. The study region is essentially a "two-oceans" system, with a cold water, upwelling dominated system on the west, where the Benguela Current exerts a major influence. In contrast, the east coast is primarily shaped by the warm tropical Agulhas Current flowing down from the north. The two systems meet on the south coast where our studies took place. Hence, the south coast is uniquely positioned to gain the advantages of high nutrient concentrations from cold upwelling currents, and warm temperatures favorable for rapid biotic growth in the warm currents.

The dependence on intertidal resources in this region might be expected to have led to important changes in the social behavior of the human foragers first exploiting those resources. The marine coast represents a rich but circumscribed habitat for huntergatherers. The resource base is dense, productive, and highly predictable in time and space, unlike the dispersed local resources (such as local geophytes [Singels, 2013], honey, ungulates) that might have been the mainstay of earlier hominin diets in the region. Ecological theory predicts that dependence on dense, predictable, resources often leads to territorial defense in animal and human societies (Brown, 1964; Dyson-Hudson and Smith, 1978; Cashdan, 1983; Grant, 1993). Drawing on this theory, it has been suggested that expansion into a coastal feeding niche could trigger active boundary defense, intergroup conflict, and subsequent adaptive increase in within-group cooperation (Marean, 2014). Areas that are worth defending are also worth invading. Possibly, amplified intergroup competition and conflict over highly productive resource patches could lead to the development of large cooperative alliances. Hence, marine resource use might ultimately be tied to the evolution of human prosociality (Bowles, 2009). Likewise, the 
advantages of exchanging complementary goods and raw materials with inland groups might possibly lead to increased social network sizes, and frequent introduction of innovations that could promote more rapid cultural evolution (Henrich, 2004; Powell et al., 2009). These and other theoretical implications of early human marine foraging should be examined more carefully.

\section{Archaeological implications}

The South African archaeological record for intertidal resource use is rich and well published, beginning at $160 \mathrm{ka}$ (Marean et al., 2007) and extending into the Holocene (Parkington, 2006; Jerardino, 2010b; Marean et al., 2014). It is one of the best studied records in coastal archaeology, but to date has not been informed by modern studies of shellfish collection return rates. Our study was designed to help illuminate this record and particularly help us understand better the significance of intertidal marine foraging for modern human origins. While our results need to be extended by modeling different sea level and habitat compositions, assessing long term depletion patterns, and by examining transport models that predict how harvested foods will be represented in archaeological assemblages, we can draw some preliminary comparisons with the archaeological record.

The changes in sea level during the Holocene have been minute relative to those in the Pleistocene. We can never study the impact of changing sea levels directly, but by studying different habitat types at different localities our goal is to cover the range of potential habitat types that existed in the past. Based on the submarine geology of the region (Cawthra, 2014; Cawthra et al., 2015) we think that changing sea levels would not have uncovered unique marine habitat types that are not sampled by this study. 
At present, high marine productivity is stimulated by the meeting of cold Benguela and warm Agulhas currents. Over the last $150 \mathrm{ka}$, the warm Agulhas Current continued to flow with only minor and insignificant shifts (Winter and Martin, 1990). Also, Agulhas seepage into the Atlantic decreased during glacial periods and allowed greater influence of the nutrient rich Benguela Current on the southern Cape coast (Little et al., 1997; Peeters et al., 2004). Thus, glacial periods during the late Pleistocene and Holocene might have been characterized by slightly elevated marine productivity

The South African Stone Age record of coastal resource use shows a diversity of patterns in mollusk species representation. Some sites have a wide diversity of species, while other sites are focused on sand beach species, or rocky intertidal species, or both. Sometimes "megamiddens" are overwhelmingly dominated by one taxon (Jerardino, 2010a). There are some LSA middens in our study area at Vleesbaai (Oestmo et al., 2014) that have huge quantities of sand mussel (D. serra) to the near exclusion of everything else, and just next to them are LSA middens with a wide diversity of species. Sometimes these patterns are present at the same site - at PP13B the mollusk sample shows some layers that are dominated by rocky-intertidal species, while others are dominated by sand beach species (Jerardino and Marean, 2010). These patterns are normally discussed in relation to changing site context and the availability of differing habitats, as well as the intensity of the foraging pattern.

Our results suggest that transport patterns to residential sites are critical to the interpretation of species abundance in archaeological assemblages. This is consistent with well-developed theory (Metcalfe and Barlow, 1992) and results from prior shellfish transport studies carried out within the framework of OFT (Meehan, 1982; Bird, 1997; 
Bird and Bliege Bird, 1997; Bird et al., 2002; Thomas, 2002, 2007). While P. perna (brown mussel) is extremely common in some Stone Age archaeological assemblages, it makes up only $12 \%$ of the harvest we observed. In contrast, $H$. spadicea (Venus ear abalone) composes over $20 \%$ of our observed harvest, yet represents a tiny portion of the shell at most archaeological sites. This cannot be explained by refuse-to-edible ratio, and utility alone, since the shell makes up $75 \%$ of the live weight of $P$. perna, but only $60 \%$ of the live weight of $H$. spadicea (Table 2). Observations on our foragers may provide some insights. P. perna was never shelled on site, but was always transported whole back to the cooking site. Haliotis spp. were always extracted from their shells before transporting home. It may be that bivalves preserve longer in the shell due to the tight seal, or that they are more difficult to extract prior to cooking. What is recovered from an archaeological living site is not always determined just by transport and refuse ratios, nor are archaeological assemblages always a good reflection of what is eaten. This is why experiments are critical to determine likely harvest irrespective of archaeological evidence. This lesson is even stronger when we consider species like octopi (Octopus vulgaris) and red bait (Pyura stolonifera) which have no hard structures to discover archaeologically yet comprised about $7 \%$ of the food energy collected in our sample. For example, Clark and Kandel (2013) estimate the kcal that shellfish contributed to MSA diets from shell weights in the archaeological deposits, and then from that they estimate how many person-days of food is documented. Our results show that this procedure will dramatically underestimate the contributions of important species like T. sarmaticus and H. spadicea that are regularly field processed, and it would thus seriously underestimate shellfish contributions to the overall diet. 
Another puzzling pattern concerns T. samarticus (turban snail), which is often abundant in archaeological sites. At Pinnacle Point they are common in the same strata where Perna perna is common, probably because both are taken together from rocky intertidal zones (Jerardino and Marean, 2010). However, in this study, P. perna was transported to the residential site whole, while T. samarticus was often extracted (raw) from its shell or cooked and extracted prior to transport home. But the extracted and transported raw portion of the snails often included the operculum, which would explain why this structure, but not snail shells, is often abundant in middens. The decision to field process $T$. samarticus may result from the rather large and heavy shell, which makes up more than $90 \%$ of the live weight collected. If field processing to reduce the shell weight is typical, and if the operculum is only transported on raw but not cooked meat, then the contribution of $T$. samarticus to ancient diets might still be underestimated, even when it is relatively abundant in an assemblage.

In some ways, our harvest patterns might resemble those of MSA foragers more closely than they resemble patterns from the Holocene. This is due to the fact that the experimental sites we studied were well-protected and had not been harvested significantly in at least 20 years. Holocene hunter-gatherers exploited fish, marine birds, and invertebrates from all intertidal zones, shell sizes for some species become significantly smaller, and the Holocene middens are denser, thicker, and more expansive, sometimes constituting "mega-middens". In the Holocene, human burials are found within the middens. While some of these patterns could result from preservation bias, there is a growing consensus that this probably reflects larger and more permanent populations in the Holocene (Klein and Steele, 2013). While Holocene foragers probably 
had to adjust to significant depletion of favored prey, our sample subjects focused on abundant large-bodied species with a strong preference for low spring tide foraging only and a near complete avoidance of small species such as Oxystele sinensis (periwinkles), or less desirable species (e.g., Scutellastra cochlear) despite their high abundance in the study sites, or prevalence in Holocene assemblages (McGrath et. al., 2016). Our harvest composition was more consistent with the narrower range of species found in MSA middens compared to LSA middens. Likewise, in our study, only men foraged in the risky cochlear zones, while women and adolescents mainly foraged in the lower balanoid zone. Perhaps that difference would disappear if attractive species became more depleted through time.

\section{Conclusion}

Experimental foraging along the South African coast between Blombos Cave and Pinnacle Point suggests that marine intertidal foraging in this region under coastline conditions similar to the present would have been quite attractive to foraging populations. Collecting invertebrates for a few hours on a few days before and after spring tides would produce on average about $600-1200 \mathrm{Kcal} \mathrm{hr}^{-1}$ for women and men, respectively, and talented men could reliably obtain $\sim 2500 \mathrm{Kcal} \mathrm{hr}^{-1}$ under average conditions. This is better than the measured hunting return rate for men in the majority of foraging societies that have been monitored carefully in recent years. Returns would vary quite notably according to habitat, weather conditions, and tidal levels. However, we observed that sex differences were moderate, and age differences, in foraging ability from nine to $60+$ years, were almost non-existent. Finally, we estimated more than a 10-fold difference in expected return rates for each sex under best and worst combinations of conditions. This 
suggests that strategic planning would be critical for human foragers in this ecology.

Regardless of high returns near spring tide dates, our experiments suggest that marine intertidal foraging on neap tide days would provide very low energetic returns. Hence, the foraging economy in this area must have included important other sources of energy and protein lipid nutrients, even when human population densities were low.

\section{Acknowledgements}

We would like to thank the communities of Melkoutfontein and Gouritzmond, and in particular Henry and Donovan Europa and David Harker, for their cooperation. We also thank the numerous landowners along the coastal study region that allowed us access to specific coastal foraging sites across private land. The support from the Department of Agriculture, Forestries and Fisheries for permits and the South African Naval Hydrographic Office for ongoing tidal information is much appreciated. This research was funded by National Science Foundation grant BCS-1138073, and by the John Templeton Foundation grant \#48952 to the ASU Institute of Human Origins’

Evolutionary Foundations of Human Uniqueness research program. 


\section{$\underline{\text { References }}$}

Bigalke, E.H., 1973. The exploitation of shellfish by coastal tribesmen of the Transkei. Annals of the Cape Province Museum (Natural History) 9, 159-175.

Bird, D.W., 1997. Behavioral ecology and the archaeological consequences of central place foraging among the Meriam. Arch. P. Am. Ant. Asso. 7, 291-306.

Bird, D.W., Bliege Bird, R.L., 1997. Contemporary shellfish gathering strategies among the Meriam of the Torres Strait Islands, Australia: testing predictions of a central place foraging model. J. Archaeol. Sci. 24, 39-63.

Bird, D. W., Bliege Bird, R.L., 2000. The ethnoarchaeology of juvenile foragers: shellfishing strategies among Meriam children. J. Anthropol. Archaeol. 19, 461-476.

Bird, D.W., Richardson, J.L., Veth, P.M., Barham, A.J., 2002. Explaining shellfish variability in middens on the Meriam Islands, Torres Strait, Australia. J. Archaeol. Sci. 29, 457-469.

Bird, D.W., Bird, R.B., Richardson, J.L., 2004. Meriam ethnoarchaeology: Shellfishing and shellmiddens. Memoirs of the Queensland Museum, Culture. 3, 183-197.

Bowles, S. 2009. Did warfare among ancestral hunter-gatherers affect the evolution of human social behaviors? Science, 324, 1293-1298.

Branch, G.M., Branch, M., 1992. The Living Shores of Southern Africa. Struik Publishers, Cape Town.

Branch, G.M., Menge, B.A., 2001. Rocky intertidal communities. In: Bertness, M.D., Gaines, S.D., Hay, M.E. (Eds.), Marine Community Ecology. Sinauer Associates, Sunderland, pp. 221-251.

Branch, G. M., Odendaal, F., 2003. The effects of marine protected areas on the population dynamics of a South African limpet, Cymbula oculus, relative to the influence of wave action. Biol. Conserv. 114, 255-269.

Broadhurst, C.L., Wang, Y., Crawford, M.A., Cunnane, S.C., Parkington, J.E., Schmidt, W.F., 2002. Brain-specific lipids from marine, lacustrine, or terrestrial food resources: potential impact on early African Homo sapiens. Comp. Biochem. Phys. B 131, 653-673.

Brown, J.L. 1964. The evolution of diversity in avian territorial systems. The Wilson Bulletin 76, 160-169..

Bustamante, R.H., Branch, G.M., Eekhout, S., Robertson, B., Zoutendyk, P., Schleyer, M., Dye, A., Hanekom, N., Keats, D., Jurd, M., McQuaid, C., 1995. Gradients of 
intertidal primary productivity around the coast of South Africa and their relationships with consumer biomass. Oecologia 102, 189-201.

Cashdan, E.A., 1983. Territoriality among human foragers: ecological models and an application to four Bushmen groups. Curr. Anthropol. 24, 47-66.

Cawthra, H.C., 2014. The marine geology of Mossel Bay, South Africa. Ph.D. Dissertation, University of Cape Town.

Cawthra, H.C., Compton, J. S., Fisher, E. C., Marean, C. W., (2015). Drowned shorelines and submerged terrestrial landscape features off the South African south coast. In: Harff, J., Bailey, G., Lüth F. (Eds.), Geology and Archaeology: Submerged landscapes of the continental shelf. Special Publication of the Geological Society of London. DOI: 10.1144/SP411.11.

Chandler, G., Merry, G., 2010. The South Africa Geoid 2010: SAGEOID10. PositionIT. 29-33.

Clark, J. L., Kandel, A.W., 2013. The evolutionary implications of variation in human hunting strategies and diet breadth during the Middle Stone Age of Southern Africa. Curr. Anthropol. 54, S269-S287.

Codding, B.F., O'Connell, J.F., Bird, D.W., 2014. Shellfishing and the colonization of Sahul: A multivariate model evaluating the dynamic effects of prey utility, transport considerations and life-history on foraging patterns and midden composition. The Journal of Island and Coastal Archaeology 9, 238-252.

Colonese, A.C., Mannino, M.A., Bar-Yosef Mayer, D.E., Fa, D.A., Finlayson, J.C., Lubell, D., Stiner, M. C., 2011. Marine mollusc exploitation in Mediterranean prehistory: an overview. Quatern. Int. 239, 86-103.

Compton, J.S., 2011. Pleistocene sea-level fluctuations and human evolution on the southern coastal plain of South Africa. Quaternary Sci. Rev. 30, 506-527.

Crittenden, A.N., 2009. Allomaternal care and juvenile foraging among the Hadza: Implications for the evolution of cooperative breeding in humans. Ph.D. Dissertation, University of California San Diego.

De Boer, W.F., Blijdenstein, A.F., Longamane, F., 2002. Prey choice and habitat use of people exploiting intertidal resources. Environ. Conserv. 29, 238-252.

Dye, A. H. 1992. Experimental studies of succession and stability in rocky intertidal communities subject to artisanal shellfish gathering. Neth. J. Sea Res. 30, 209-217.

Dyson-Hudson, R., Smith, E.A., 1978. Human territoriality: an ecological reassessment. Am. Anthropol. 80, 21-41. 
Dwyer, P.D., 1974. The price of protein: Five hundred hours of hunting in the New Guinea highlands. Oceania 278-293.

Erlandson, J.M., 1988. The role of shellfish in prehistoric economies: a protein perspective. Am. Antiquity 53, 102-109.

Erlandson, J.M., 2001. The archaeology of aquatic adaptations: Paradigms for a new millennium. J. Archaeol. Res. 9, 287-350.

Fa, D.A., 2008. Effects of tidal amplitude on intertidal resource availability and dispersal pressure in prehistoric human coastal populations: the Mediterranean-Atlantic transition. Quaternary Sci. Rev. 27, 2194-2209.

Fisher, E.C., Bar-Matthews, M., Jerardino, A., Marean, C.W., 2010. Middle and Late Pleistocene paleoscape modeling along the southern coast of South Africa. Quaternary Sci. Rev. 29, 1382-1398.

Grant, J.W.A. 1993. Whether or not to defend? The influence of resource distribution. Mar. Freshw. Behav. Phy. 23, 137-153.

Hawkes, K., O'Connell, J.F., Jones, N.B., Oftedal, O.T., Blumenschine, R.J., 1991. Hunting income patterns among the Hadza: big game, common goods, foraging goals and the evolution of the human diet [and discussion]. Phil.Trans. R. Soc. B 334, 243-251.

Hawkes, K., O’Connell, J.F., Jones, N.G.B., 2014. More lessons from the Hadza about men's work. Hum. Nature 25, 596-619.

Henn, B.M., Gignoux, C.R., Jobin, M., Granka, J.M., Macpherson, J.M., Kidd, J.M., Rodriquez-Botigué, L., Ramachandran, S., Hon, L., Brisbin, A., Lin, A.A., Underhill, P.A., Comas, D., Kidd, K.K., Norman, P.J., Parham, P., Bustamante, C.D., Mountain, J.L., Feldman, M.W., 2011. Hunter-gatherer genomic diversity suggests a southern African origin for modern humans. Proc. Natl. Acad. Sci. 108, 5154-5162.

Henrich, J., 2004. Demography and cultural evolution: how adaptive cultural processes can produce maladaptive losses: the Tasmanian case. Am. Antiquity 197-214.

Henshilwood, C.S., Nilssen, P., Parkington, J., 1994. Mussel drying and food storage in the late Holocene, SW Cape, South Africa. J. Field Archaeol. 21, 103-109.

Henshilwood, C.S., Sealy, J.C., Yates, R.J., Cruz-Uribe, K., Goldberg, P., Grine, F.E., Klein, R.G., Poggenpoel, C., van Niekerk, K., Watts, I., 2001. Blombos Cave, southern Cape, South Africa: Preliminary report on the 1992-1999 excavations of the Middle Stone Age levels. J. Archaeol. Sci. 28, 421-448.

Hill, K., 1982. Hunting and human evolution. J. Hum. Evol. 11, 521-544. 
Hill, K., 1988. Macronutrient modifications of optimal foraging theory: an approach using indifference curves applied to some modern foragers. Hum. Ecol. 16, 157-197.

Hill, K., Hawkes, K., 1983. Neotropical hunting among the Ache of eastern Paraguay. In: Hames, R.B., Vickers, W.T. (Eds.), Adaptive Responses of Native Amazonians. Academic Press, New York, pp. 139-188.

Hill, K., Hurtado, A.M., 2009. Cooperative breeding in South American hunter-gatherers. Phil. Trans. R. Soc. 276, 3863-3870.

Hill, K., Kaplan, H., Hawkes, K., Hurtado, A.M., 1987. Foraging decisions among Ache hunter-gatherers: new data and implications for optimal foraging models. Ethol. Sociobiol. 8, 1-36.

Hockey, P. A., Bosman, A. L., 1986. Man as an intertidal predator in Transkei: disturbance, community convergence and management of a natural food resource. Oikos 46, 3-14.

Hockey, P.A.R., Bosman, A.L., Siegfried, W.R., 1988. Patterns and correlates of shellfish exploitation by coastal people in Transkei: An enigma of protein production. J. Appl. Ecol. 353-363.

Hurtado, A.M., Hill, K.R., 1990. Seasonality in a foraging society: variation in diet, work effort, fertility, and sexual division of labor among the Hiwi of Venezuela. J. Anthropol. Res. 293-346.

Jerardino, A., 2010a. Large shell middens in Lamberts Bay, South Africa: a case of hunter-gatherer resource intensification. J. Archaeol. Sci. 37, 2291-2302.

Jerardino, A., 2010b. Prehistoric exploitation of marine resources in Southern Africa with particular reference to shellfish gathering: opportunities and continuities. Pyrenae 41, 752.

Jerardino, A., Marean, C.W., 2010. Shellfish gathering, marine paleoecology and modern human behavior: perspectives from cave PP13B, Pinnacle Point, South Africa. J. Hum. Evol. 59, 412-424.

Jones, N.B., Marlowe, F.W., 2002. Selection for delayed maturity. Hum. Nature 13, 199238.

Jones, R., 1980. Hunters in the Australian coastal savanna. In: Harris, D.R. (Ed.), Human Ecology in Savanna Environments. Academic Press, London, pp. 107-146. 
Jones, T.L., Richman, J.R., 1995. On mussels: Mytilus californianus as a prehistoric resource. N. Am. Archaeol. 16, 33-58.

Kim, H.L., Ratan, A., Perry, G.H., Montenegro, A., Miller, W., Schuster, S.C., 2014. Khoisan hunter-gatherers have been the largest population throughout most of modernhuman demographic history. Nat. Commun. 5. DOI: 10.1038/ncomms6692.

Kennedy, M.A., 2004. An investigation of hunter-gatherer shellfish foraging practices: archaeological and geochemical evidence from Bodega Bay, California. Ph.D. Dissertation, University of California, Davis.

Klein, R.G., Steele, T.E., 2013. Archaeological shellfish size and later human evolution in Africa. Proc. Natl. Acad. Sci. 110.27, 10910-10915.

Kyle, R., Pearson, B., Fielding, P.J., Robertson, W.D., Birnie, S.L., 1997a. Subsistence shellfish harvesting in the Maputaland Marine Reserve in northern KwaZulu-Natal, South Africa: Rocky shore organisms. Biol. Conserv. 82, 183-192.

Kyle, R., Robertson, W.D., Birnie, S.L., 1997b. Subsistence shellfish harvesting in the Maputaland Marine Reserve in northern KwaZulu-Natal, South Africa: Sand beach organisms. Biol. Conserv. 82, 173-182.

Kyriacou, K., Parkington, J.E., Marais, A.D., Braun, D.R., 2014. Nutrition, modernity and the archaeological record: Coastal resources and nutrition among Middle Stone Age hunter-gatherers on the western Cape coast of South Africa. J. Hum. Evol. 77, 64-73.

Lambert, G., Steinke, T. D., 1986. Effects of destroying juxtaposed mussel-dominated and coralline algal communities at Umdoni Park, Natal coast, South Africa. S. Afr. J. Marine Sci. 4, 203-217.

Langejans, G.H.J., van Niekerk, K.L., Dusseldorp, G.L., Thackeray, J.F., 2012. Middle Stone Age shellfish exploitation: Potential indications for mass collecting and resource intensification at Blombos Cave and Klasies River, South Africa. Quatern. Int. 270, 8094.

Lasiak, T.A., 1992. Contemporary shellfish-gathering practices of indigenous coastal people in Transkei: some implications for interpretation of the archaeological record. S. Afr. J. Sci. 88, 19-28.

Lasiak, T., Dye, A., 1989. The ecology of the brown mussel Perna perna in Transkei, Southern Africa: Implications for the management of a traditional food resource. Biol. Conserv. 47, 245-257.

Lasiak, T.A., Field, J.G., 1995. Community-level attributes of exploited and nonexploited rocky infratidal macrofaunal assemblages in Transkei. J. Exp. Mar. Biol. Ecol. 185, 33-53. 
Lasiak, T. 1999. The putative impact of exploitation on rocky infratidal macrofaunal assemblages: a multiple-area comparison. J. Mar. Biol. Assoc. UK. 79, 23-34.

Little, M. G., Schneider, R.R., Kroon, D., Price, B., Bickert, T., Wefer, G., 1997. Rapid palaeoceanographic changes in the Benguela Upwelling System for the last 160,000 years as indicated by abundances of planktonic foraminifera. Palaeogeogr. Palaeoclimatol. Palaeoecol. 130, 135-161.

Mannino, M. A., Thomas, K.D., 2002. Depletion of a resource? The impact of prehistoric human foraging on intertidal mollusc communities and its significance for human settlement, mobility and dispersal. World Archaeol. 33, 452-474.

Marean, C.W., 2010. Pinnacle Point Cave 13B (Western Cape Province, South Africa) in context: The Cape Floral kingdom, shellfish, and modern human origins. J. Hum. Evol. $59,425-443$.

Marean C.W., 2011. Coastal South Africa and the co-evolution of the modern human lineage and coastal adaptations. In: Bicho, N.F., Haws, J.A., Davis, L.G. (Eds.), Trekking the Shore: Changing Coastlines and the Antiquity of Coastal Settlement. Springer Science \& Business Media, New York, pp. 421-440.

Marean, C.W., 2014. The origins and significance of coastal resource use in Africa and Western Eurasia. J. Hum. Evol. 77, 17-40.

Marean, C.W., Bar-Matthews, M., Bernatchez, J., Fisher, E., Goldberg, P., Herries, A.I.R., Jacobs, Z., Jerardino, A., Karkanas, P., Minichillo, T., Nilssen, P.J., Thompson, E., Watts, I., Williams, H.M., 2007. Early human use of marine resources and pigment in South Africa during the Middle Pleistocene. Nature 449, 905-908.

Marean, C.W., Cawthra, H.C., Cowling, R.M., Esler, K.J., de Vynck, J., 2014. Stone Age people in a changing South African Greater Cape Floristic Region. In: Allsopp, N., Colville, J.F., Verboom, T. (Eds.), Fynbos: Ecology, Evolution, and Conservation of a Megadiverse Region. Oxford University Press, Oxford, pp. 164-199.

Mather, A.A., Garland, G.G., Stretch, D.D., 2009. Southern African sea levels: corrections, influences and trends. Afr. J. Mar. Sci. 31, 145-156.

McGrath, J.R., Cleghorn, N., Gennari, B., Henderson, S., Kyriacou, K., Nelson-Viljoen, C., Nilssen, P., Richardson, L., Shelton, C., Wilkins, J., Marean, C.W., 2016. The Pinnacle Point shell midden complex: A high resolution Mid- to Late Holocene record of Later Stone Age coastal foraging along the southern Cape coast of South Africa. In press, S. Afr. Archaeol. Bull..

Metcalfe, D., Barlow, K.R., 1992. A model for exploring the optimal trade-off between field processing and transport. Am. Anthropol. 94, 340-356. 
Meehan, B., 1982. Shell Bed to Shell Midden.Australian Institute of Aboriginal Studies, Canberra.

Navy, South African. 2015. South African tide tables. South African Navy, Tokai, South Africa.

Oestmo, S., Schoville, B.J., Wilkins, J., Marean, C.W., 2014. A Middle Stone Age Paleoscape near the Pinnacle Point caves, Vleesbaai, South Africa. Quatern. Int. 350, 147-168.

Parkington, J., 2006. Shorelines, Strandlopers and Shell Middens. Krakadouw Trust, Cape Town.

Peeters, F.J., Acheson, R., Brummer, G.J.A., De Ruijter, W.P., Schneider, R.R., Ganssen, G.M., Ufkes, E., Kroon, D., 2004. Vigorous exchange between the Indian and Atlantic oceans at the end of the past five glacial periods. Nature 430, 661-665.

Penn, D.C., Povinelli, D.J., 2007. Causal cognition in human and nonhuman animals: A comparative, critical review. Annu. Rev. Psychol. 58, 97-118.

Penn, D.C., Holyoak, K.J., Povinelli, D.J., 2008. Darwin's mistake: Explaining the discontinuity between human and nonhuman minds. Behav. Brain Sci. 31, 109-130.

Powell, A., Shennan, S., Thomas, M.G., 2009. Late Pleistocene demography and the appearance of modern human behavior. Science 324, 1298-1301.

Rick, T.C., Erlandson, J. (Eds), 2008. Human Impacts on Ancient Marine Ecosystems: A Global Perspective. University of California Press, Berkeley.

Robinson, J., 2000. Calculating maximum sustainable harvest and percentage offtakes. In: J. Robinson, J., Bennett, E. (Eds.), Hunting for Sustainability in Tropical Forests. Columbia University Press, New York, pp. 521-524.

Siegfried, W.R., Hockey, P.A., Crowe, A.A., 1985. Exploitation and conservation of brown mussel stocks by coastal people of Transkei. Environ. Conserv. 12, 303-307.

Singels, E., 2013. Underground storage organs of plants as a food source for Pleistocene hunter-gatherers in the Southern Cape. MSc. Thesis, Stellenbosch University.

Speth, J.D., Spielmann, K.A., (1983). Energy source, protein metabolism, and huntergatherer subsistence strategies. J. Anthropol. Archaeol. 2, 1-31.

Steele, T.E., Klein, R.G., 2008. Intertidal shellfish use during the Middle and Later Stone Age of South Africa. Archaeofauna 17, 63-76.

Thackeray, J.F., 1988. Molluscan fauna from Klasies River, South Africa. S. Afr. Archaeol. Bull. 43, 27-32. 
Thomas, D.H. (Ed.), 2008. Native American landscapes of St. Catherines Island, Georgia. American Museum of Natural History, New York.

Thomas, F.R., 2002. An evaluation of central-place foraging among mollusk gatherers in Western Kiribati, Micronesia: Linking behavioral ecology with ethnoarchaeology. World Archaeol. 34, 182-208.

Thomas, F.R., 2007. The behavioral ecology of shellfish gathering in western Kiribati, Micronesia 1: Prey choice. Hum. Ecol. 35, 179-194.

Tishkoff, S.A., Reed, F.A., Friedlaender, F.R., Ehret, C., Ranciaro, A., Froment, A., Hirbo, J.B., Awomoyi, A.A., Bodo, J., Doumbo, O., Ibrahim, M., Juma, A.T., Kotze, M.J., Lema, G., Moore, J.H., Mortensen, H., Nyambo, T.B., Omar, S.A., Powell, K., Pretorius, G.S., Smith, M.W., Thera, M.A., Wambebe, C., Weber, J.L., Williams, S.M., 2009. The genetic structure and history of Africans and African Americans. Science 324, 1035-1044.

Tomalin, B. J., Kyle, R., 1998. Subsistence and recreational mussel (Perna perna) collecting in KwaZulu-Natal, South Africa: fishing mortality and precautionary management. S. Afr. J. Zool. 33, 12-22.

Voigt, E., 1973. Klasies River Mouth Cave: An exercise in shell analysis. Bulletin of the Transvaal Museum 14, 14-15.

Whitaker, A.R., 2008. Incipient aquaculture in prehistoric California?: Long-term productivity and sustainability vs. immediate returns for the harvest of marine invertebrates. J. Archaeol. Sci. 35, 1114-1123.

Whitaker, A.R., Byrd, B.F., 2014. Social circumscription, territoriality, and the late Holocene intensification of small-bodied shellfish along the California coast. The Journal of Island and Coastal Archaeology. 9, 150-168.

Winter, A., Martin, K. 1990. Late Quaternary history of the Agulhas current. Paleoceanography 5, 479-486.

Wisuki, 2015. Still Bay, Western Cape, South Africa. Retrieved March 19, 2015, from http://wisuki.com/statistics/5384/still-bay.

Wood, B.M., Marlowe, F.W., 2013. Household and kin provisioning by Hadza men. Hum. Nature 24, 280-317.

Wood, B.M., Marlowe, F.W., 2014. Toward a reality-based understanding of Hadza men's work. Hum. Nature 25, 620-630. 
World Weather Online, 2015. Still Bay West Monthly Climate Average, South Africa. Retrieved March 19, 2015, from http://www.worldweatheronline.com/Still-Bay-Westweather-averages/Western-Cape/ZA.aspx. 


\section{Figure Captions:}

Figure 1. Study Area. The study area from Blombos Cave to Pinnacle Point was walked at low tide and habitats of aeolianite (Ae), TMS boulders (B), TMS rocky headlands (ERH), sand beach (S), and TMS wave-cut platforms (WCP) were recorded each 100 meters. The black lines show the area surveyed and the yellow lines show the extent of each habitat type. Elevations are indicated in meters above current sea level.

Figure 2. Bout lengths and observed return rates in the foraging sample $(n=531)$. The frequency of the return rate values logged is normally distributed. Extreme high return rates were observed over only short observation periods. For this reason regressions were performed on data weighted by bout length.

Figure 3. Caloric composition of the harvest from 2012 to 2015 (see Table 2 for details).

Figures 4a-c. Predicted marginal mean return rates from the gamma log-linked model. Predicted marginal mean return rates from the gamma log-linked model for categorical variables with other variables set to mean value proportions in Table 3. Inclusion of random effects in this model gives the predicted return rates for a forager of mean individual skill level in the sample database. Error bars show 95\% confidence intervals under mean conditions.

Figures 5a-b. LOWESS smooth of residual bout return rate by tidal level or subject age. A GLM model including all variables except age (a), or tide level (b) was used to predict the expected return rate for each observed bout. This was then subtracted from the measured bout return rate, to get the residual, which is then plotted to show the effect of age (a) or tide level (b) on foraging return rate with all other variables controlled.

Figure 6. Individual return rate variation. Mean return rate for 11 foragers that were observed for at least eight hours over at least four foraging days. 95\% confidence intervals (error bars) were generated by resampling with replacement 10,000 times from each forager's set of bout specific return rates. 
Table 1. Sample characteristics (Rocky Coastline ${ }^{a}$ )

\begin{tabular}{llllllllll}
\hline Male age & bouts & Female age & bouts & Weather & bouts & Habitat & bouts & Tidal level & bouts \\
\hline $9-25$ & 79 & $9-25$ & 24 & 1 & 29 & Sand beach 0 & $0-20 \mathrm{~cm}$ & 10 \\
$26-35$ & 108 & $26-35$ & 17 & 2 & 312 & Aeolianite & 99 & $21-40 \mathrm{~cm}$ & 140 \\
$36-45$ & 134 & $36-45$ & 23 & 3 & 131 & TMS RH & 199 & $41-60 \mathrm{~cm}$ & 230 \\
$46-55$ & 33 & $46-55$ & 64 & 4 & 59 & TMS WCP & 141 & $61-80 \mathrm{~cm}$ & 131 \\
$56-65$ & 49 & $56-65$ & 0 & 5 & 0 & TMS Boulder 92 & $81-100 \mathrm{~cm}$ & 20 \\
\hline
\end{tabular}

${ }^{\mathrm{a}}$ Data on sand beach foraging eliminated from this table. 
Table 2. Collected resources and energy content.

\begin{tabular}{|c|c|c|c|c|c|c|c|}
\hline \multirow[b]{2}{*}{ Scientific name } & \multirow[b]{2}{*}{ Common name } & \multirow{2}{*}{$\begin{array}{l}\text { Mean wt } \\
\text { (g) per item }\end{array}$} & \multicolumn{2}{|c|}{ Edible Proportion } & \multicolumn{2}{|c|}{ Kcal/kg edible portion ${ }^{\mathrm{a}}$} & \multirow{2}{*}{$\begin{array}{l}\text { Live wt. } \\
\mathrm{Kcal} / \mathrm{kg}^{\mathrm{b}}\end{array}$} \\
\hline & & & raw & cooked & raw & cooked & \\
\hline Burnupena cincta & Ridged burnupena & 40.0 & & 0.230 & & 1347 & 310 \\
\hline Charonia lampas post. & Pink lady & 250.0 & & 0.230 & & 1347 & 310 \\
\hline Cymbula miniata & Pink-rayed limpet & 46.1 & & 0.109 & 885 & 885 & 96 \\
\hline Cymbula oculus & Goat's eye limpet & 38.0 & & 0.260 & 885 & 885 & 230 \\
\hline Dinoplax gigas & Giant chiton & 63.5 & & 0.251 & & 885 & 222 \\
\hline$D_{0 n a x}$ serra $^{c}$ & White mussel & 39.2 & 0.276 & 0.176 & & 1367 & 241 \\
\hline Haliotis midae & Abalone & 190.9 & 0.378 & 0.366 & & 1782 & 653 \\
\hline Haliotis spadicea & Venus ear abolone & 44.6 & 0.514 & 0.395 & & 1782 & 703 \\
\hline Octopus vulgaris & Common octopus & 766.9 & 0.387 & & 820 & & 318 \\
\hline Oxystele sinensis & Pink-lipped topshel & 7.8 & & 0.230 & & 1347 & 310 \\
\hline Perna perna & Brown mussel & 44.7 & & 0.241 & & 1367 & 329 \\
\hline Pinctada capensis & Cape pearl oyster & 258.2 & 0.130 & & 729 & & 95 \\
\hline Plagusia chabrus & Cape rock crab & 78.8 & 0.200 & & 940 & & 170 \\
\hline Pyura stolonifera & Red bait & 42.3 & 0.950 & & 700 & & 665 \\
\hline Scutellastra argenvillei & Argenville's limpet & 56.4 & & 0.251 & 885 & 885 & 222 \\
\hline Scutellastra barbara & Bearded limpet & 50.6 & & 0.251 & & 885 & 222 \\
\hline Scutellastra cochlear & Pear limpet & 28.3 & & 0.331 & 885 & 885 & 293 \\
\hline Scutellastra costata & not reported & 57.5 & & 0.251 & 885 & 885 & 222 \\
\hline Scutellastra longicosta & Long spined limpet & 64.4 & & 0.251 & 885 & 885 & 222 \\
\hline Scutellastra tabularis & Giant tabular limpe & 170.6 & 0.145 & & 885 & 885 & 129 \\
\hline Striostrea margaritacec & Cape rock oyster & 102.5 & 0.100 & & 729 & & 73 \\
\hline Turbo sarmaticus & Turban snail & 141.2 & 0.107 & 0.075 & & 1347 & 101 \\
\hline
\end{tabular}

${ }^{a}$ See Supplementary Online Material (SOM) for source of caloric values.

${ }^{\mathrm{b}} \mathrm{Kcal}$ per kilogram as collected and weighed on site.

'Donax Serra not included in total harvest percent. 
Table 3. Linear Mixed Model ${ }^{\mathrm{a}}$

\begin{tabular}{|c|c|c|c|c|c|}
\hline Parameter & Mean & Estimate & Std. error & & $p$ value \\
\hline Intercept & NA & 7.703 & 0.293 & 26.26 & $<0.001$ \\
\hline Age & 39 & -0.001 & 0.005 & -0.15 & 0.877 \\
\hline $\operatorname{Sex}(M=1)$ & 0.76 & 0.590 & 0.179 & 3.30 & 0.001 \\
\hline $\operatorname{Sex}(F=0)$ & 0.24 & Baseline & & & \\
\hline Tide Level & 0.49 & -1.073 & 0.210 & -5.10 & $<0.001$ \\
\hline Aeolianite (1) & 0.19 & Baseline & & & \\
\hline TMS RH (2.1) & 0.37 & -0.252 & 0.105 & -2.40 & 0.017 \\
\hline TMS WCP (2.2) & 0.27 & -0.224 & 0.119 & -1.88 & 0.061 \\
\hline TMS boulders & 0.17 & -0.157 & 0.136 & -1.16 & 0.246 \\
\hline Best conditions & 0.05 & Baseline & & & \\
\hline Good conditions & 0.59 & -0.199 & 0.136 & -1.47 & 0.143 \\
\hline Poor conditions & 0.25 & -0.728 & 0.145 & -5.02 & $<0.001$ \\
\hline $\begin{array}{l}\text { Worst conditions } \\
\text { Individual random }\end{array}$ & 0.11 & -1.165 & 0.155 & -7.51 & $<0.001$ \\
\hline effect (47 levels) & & 16.333 & 1.059 & & $<0.001$ \\
\hline
\end{tabular}

aDependent Variable: Rate, Distribution; Gamma, Link Function: Log; Model Fixed Effects: (Intercep 
Table 4. Bouts of field processing prior to transport.

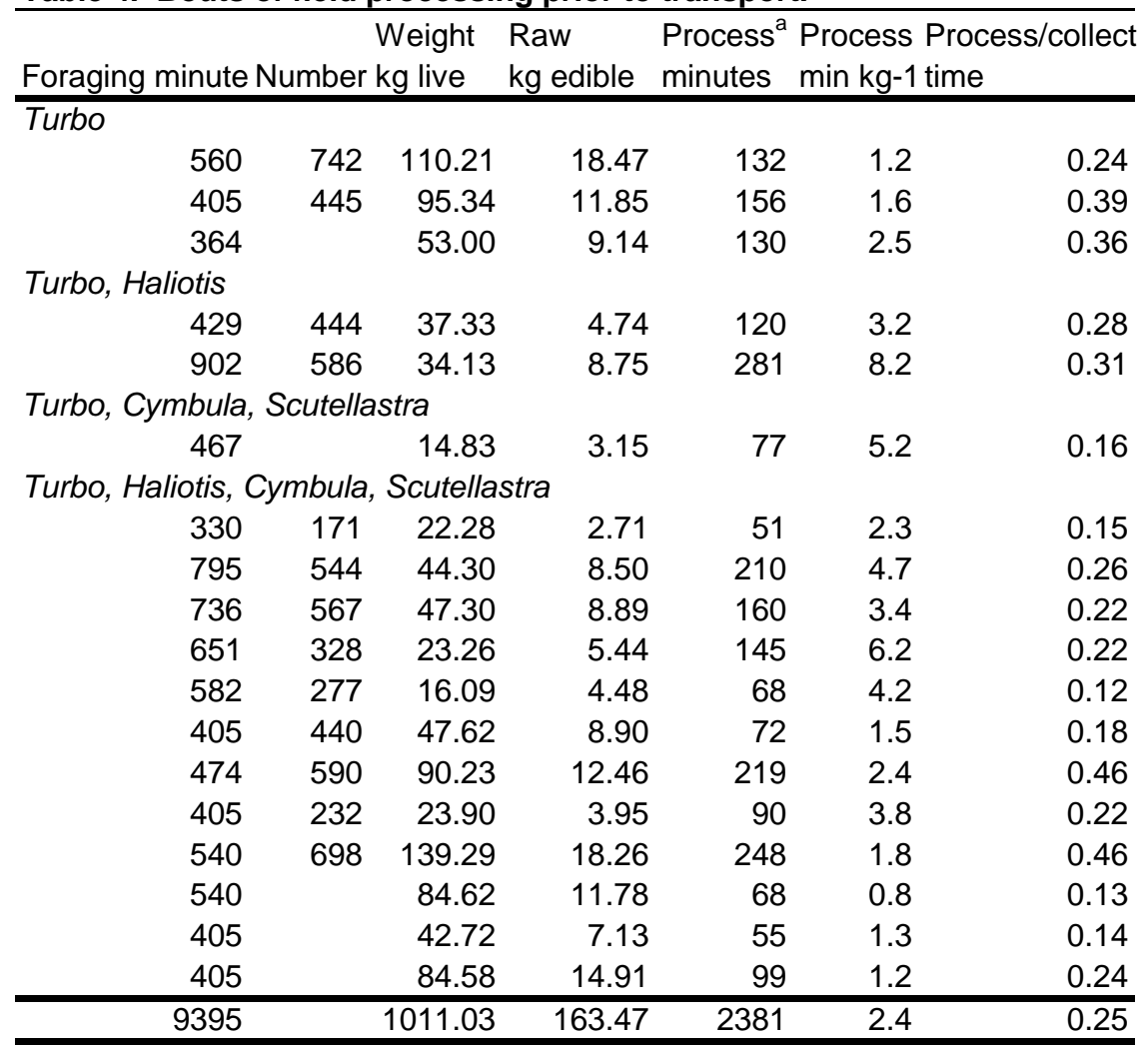

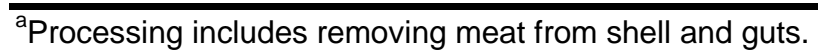


Table 5. Comparative foraging return rates from marine foraging ${ }^{a}$, pla

\begin{tabular}{|c|c|c|c|}
\hline Group & Foraging activity & Kcal hr $^{-1}$ On Site & Process ${ }^{\circ}$ \\
\hline Hiwi Women & "Jatsiro" root & 8489 Yes & No \\
\hline Hiwi Men & Hunting & 3055 No & No \\
\hline Experimental & California mussels & 2089 Yes & No \\
\hline Mer Island Adults & Reef flat shellfish & 1492 Yes & Partial \\
\hline Khoi-San Adults & Marine intertidal & 1492 Yes & No \\
\hline Hadza Men 1 & Hunting & 1410 No & No \\
\hline Ache Men & Hunting and honey & 1340 No & No \\
\hline !Kung Women & Mongongo gathering & 1300 No & Yes \\
\hline Yora Men & Aquatic foraging & 1290 No & No \\
\hline Ache Women & Palm extraction & 1268 Yes & No \\
\hline Anbarra Women & Tuber collection & 1250 No & No \\
\hline Anbarra Women & Cycad processing & 1250 No & Partial \\
\hline Hadza Women & Ekwa root & 1130 Yes & No \\
\hline Hadza Men 2 & Hunting & 1012 No & No \\
\hline Anbarra Women & Shellfish & 1000 No & No \\
\hline Hadza Men 3 & Hunting & 938 No & No \\
\hline Mbuti Men & Spear hunting & 817 No & No \\
\hline !Kung Men & Hunting & 779 No & No \\
\hline Anbarra Women & Marine intertidal & 767 Yes & No \\
\hline Hiwi Women & Plant foraging & 763 No & No \\
\hline Ache Men & Bow hunting & 610 No & \\
\hline Gwi Men & Hunting & 610 No & No \\
\hline Mer Island Adults & Rocky shore shellfist & 575 Yes & Partial \\
\hline Kiribati Women & Leeward reef & 546 Yes & Yes \\
\hline Mozambique Women & Crabs, shellfish & 508 Yes & No \\
\hline Anbarra Men & Marine intertidal & 494 Yes & No \\
\hline Mbuti Both Sexes & Net hunting & 493 No & Yes \\
\hline Mozambique Women & Crabs, shellfish & 436 Yes & No \\
\hline Khoisan Tribesmen & Marine Intertidal & 407 No & No \\
\hline Kiribati Women & Seagrass & 402 Yes & Yes \\
\hline Kiribati Women & Sandflat & 300 Yes & Yes \\
\hline Gunwinggu Women & Plant collection & 188 No & No \\
\hline Kiribati Women & Reef flats & 156 Yes & Yes \\
\hline Mbuti Men & Bow hunting & 143 No & No \\
\hline Kiribati Women & Nearshore & 120 Yes & Yes \\
\hline Kiribati Women & Reef crest & 96 Yes & Yes \\
\hline Hadza Experimental & Small game & 53 No & No \\
\hline
\end{tabular}

\footnotetext{
${ }^{a}$ Marine intertidal foraging highlighted in gray.

b"On site" measure includes all search and pursuit over a period of time, bc foraging site. These are sometimes referred to as "in patch" foraging retur ${ }^{c}$ Process $=$ Yes: food preparation and cooking, as well as acquisition, was $\mathrm{i}$ processing for transport was included in the rate, but not cleaning and cook in the rate (no processing of any kind)

${ }^{d}$ For notes, please see SOM.
} 

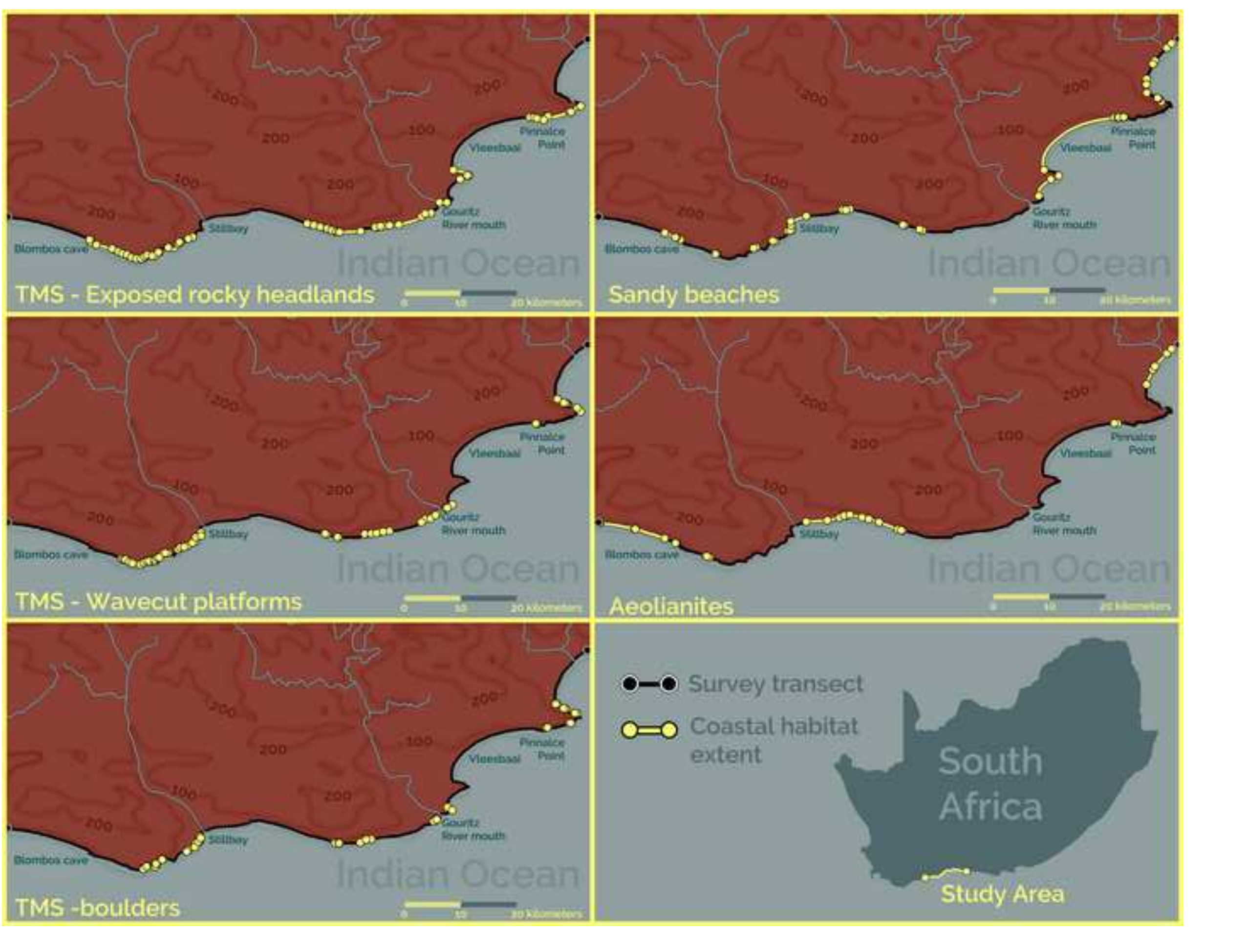
Figure 2

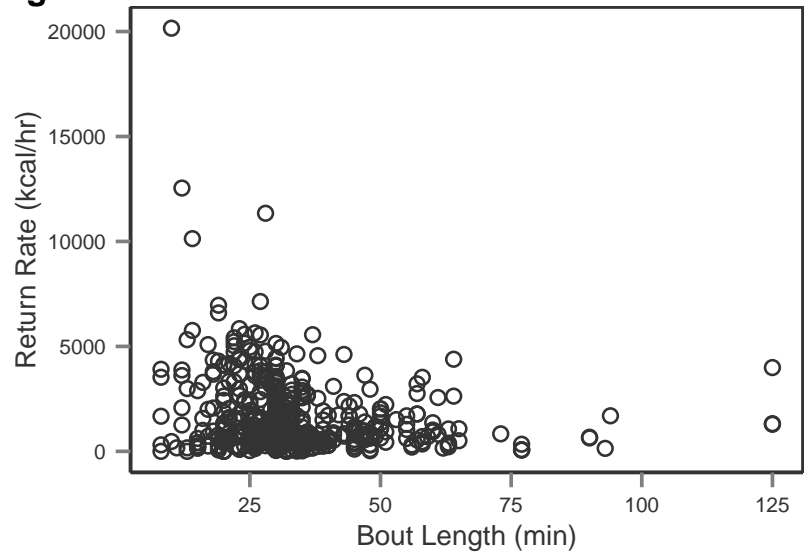


Figure $4 \mathbf{a}$

춘

돌

똔

1500

ธั

है है

产艺

สั

E

足

ш

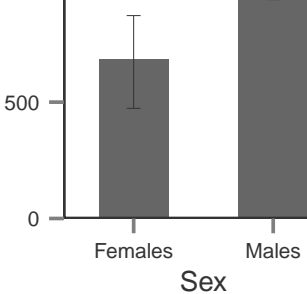


Figure $\mathbf{4 b}$
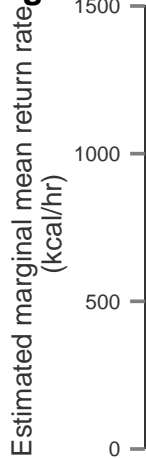

500

0

Aeolianite

Wave cut

Exposed

platforms

headlands

Habitat 
Figure $4 \mathbf{~ C}$

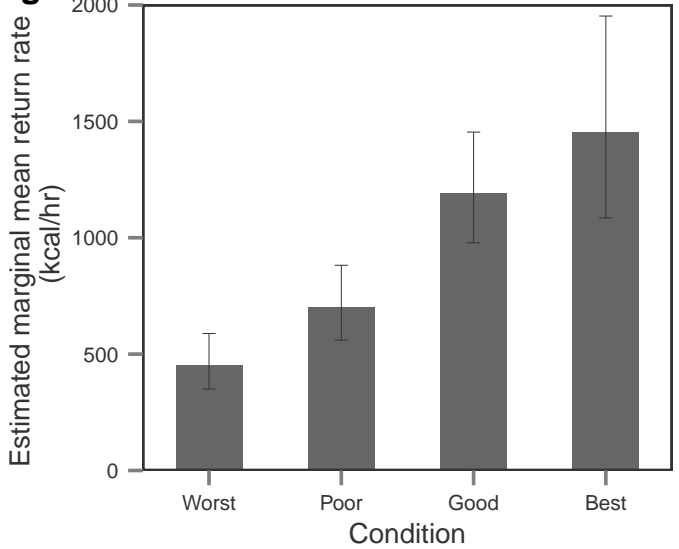




\section{Figure 5a}

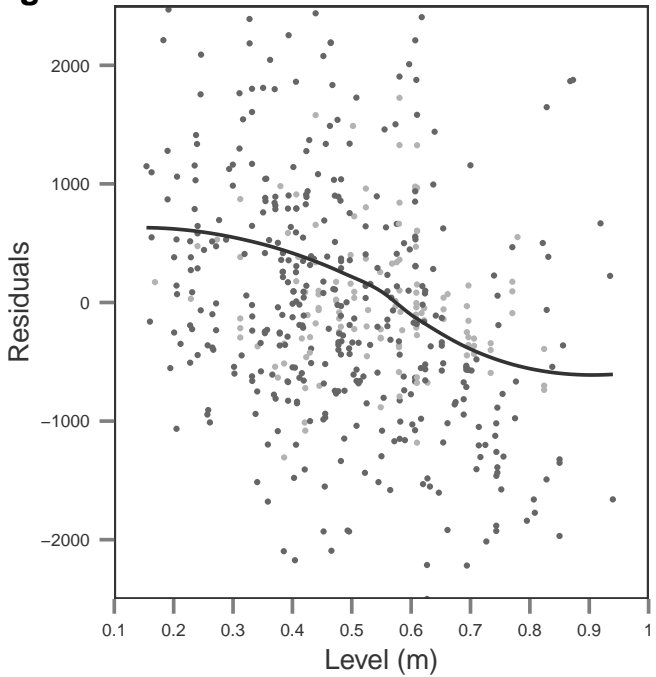

\section{Sex}

Females

- Males 


\section{Figure 5b}

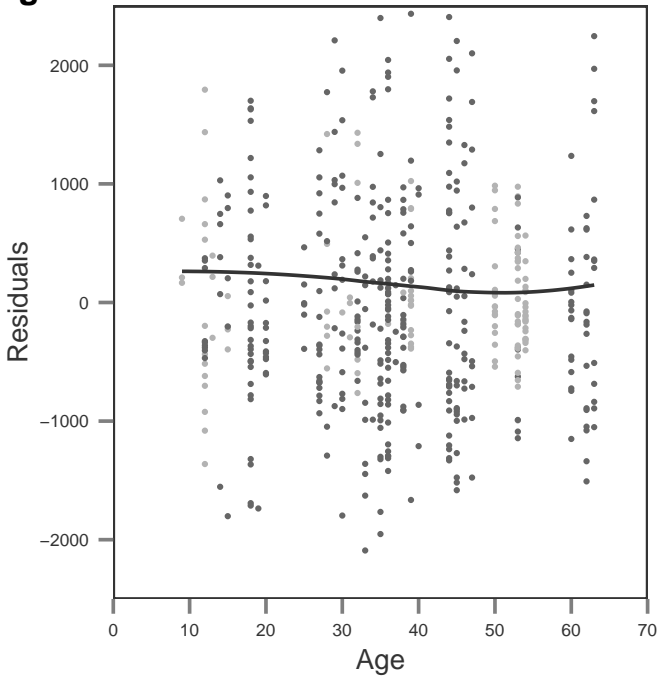

Sex

Females

- Males 
Figure $\mathbf{6}$

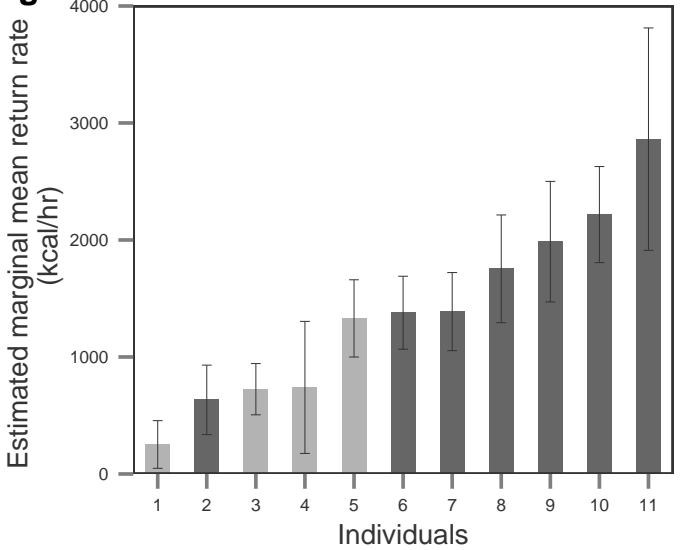

Sex Females Males 